\title{
HOST RANGE AND INCIDENCE OF HABROLEPIS DIASPIDI (HYMENOPTERA : ENCYRTIDEA) AS A PARASITOID OF ARMORED SCALE INSECTS (HEMIPTERA: DIASPIDIDIAE)
}

\author{
SHAABAN ABD-RABOU and HODA BADARY
}

Plant Protection Research Institute, ARC, Dokki, Giza

(Manuscript received 12 February 2012)

\begin{abstract}
The encyrtid parasitoid, Habrolepis diaspidi (Risbec) (Hymenoptera : Encyrtidea) is one of the most effective parasitoid associated with armored scale insects (Hemiptera: Diaspididiae). This work dealt with the host insect range and the occurance of the parasitoid, $H$. diaspidi in different localities during 2010 and 2011 in Egypt. The results indicated that the parasitoid, H. diaspidi was reared from 10 species of armored scale insects. The host armored scale insects were Aonidiella aurantii (Maskell), Aonidiella citrina (Coquillett), Aspidiotus nerii Bouche, Chrysomphalus aonidum (L.) , Chrysomphalus dictyospermi (Morgan), Hemiberlesia lataniae (Signoret), Lepidosaphes beckii (Newman), Lepidosaphes pallida (Maskell), Mycetaspis personata (Comstock), Parlatoria ziziphi (Lucas) (Hemiptera: Diaspididiae). Population abundance studies of $\mathrm{H}$. diaspidi were carried out on aforementioned armored scale insects at eight locations in Egypt, being Behira , Beni Seuf, Cairo, Giza, Ismailia , North Sinai, Qalyubiya and Sharqiya .The highest rate of parasitism attained with $H$. lataniae showed 56.8 and $77.8 \%$ during the first and second years, respectively. While lowest parasitism rates was 14.9 and $17.5 \%$ during the two years under consideration, respectively. As a general trend $H$. diaspidi was the effective parasitoid attacking armored scale insects in Egypt.

KEY WORDS: Encyrtidea, Habrolepis diaspidi, Diaspididiae, armored scale insect and Host range.
\end{abstract}

\section{INTRODUCTION}

The parasitoid, Habrolepis diaspidi (Risbec) (Hymenoptera : Encyrtidea) is one of the most dominant parasitoid of armored scale insects ( Hemiptera: Diaspididae) . Its role in controlling armored scale insects was studied by (Compere and Annecke , 1961, Trjapitzin, 1989 and Noyes and Hayat,1994 ). Bénassy and Euverte (1968) reported the seasonal abundance of this parasitoids. In Egypt many authors have been attracted with the parasitoid, H. diaspidi (Hassanein and Hamed, 1986, Abd-Rabou, 1997, Coll and Abd-Rabou, 1998, Tawfik and Mohammad, 2001 and Mohammad et al., 2001). Aonidiella aurantii (Maskell) , Aonidiella orientalis (Newstead) Chrysomphalus aonidum (Linnaeus), Chrysomphalus dictyospermi (Morgan), Hemiberlesia lataniae (Signoret), Parlatoria ziziphi (Lucas) were recorded as a host insects of this parasitoid by Trjapitzin (1989), Mohammad et al. ( 2001), Cilliers 
(1970, Bénassy and Euverte (1968), Tawfik and Mohammad (2001) and Abd-Rabou (1997), respectively.

The aim of this work is to study host insect range and the occurrence of the parasitoid, $\boldsymbol{H}$. diaspidi in different localities in Egypt.

\section{MATERIALS AND METHODS}

Samples of armored scale insects were collected from different host plants in Egypt throughout the period of study 2010 and 2011. As this parasitoid was found to exist in ten locations a incidence was conducted on different stages of $A$. aurantii on citrus (Citrus sp.) in Beni Seuf, Aonidiella citrina (Coquillett) on citrus (Citrus sp.) in Behira , Aspidiotus nerii Bouche on oleander in Giza, C. aonidum on citrus (Citrus sp.) in Qalyubiya , C. dictyospermi on Ficus nitida in Qalyubiya, H. lataniae on mango (Mangifera indica) in Ismailia, Lepidosaphes beckii (Newman) on mango (Mangifera indica) in Sharqiya, Lepidosaphes pallida (Maskell) on mango (Mangifera indica) in Qalyubiya Mycetaspis personata (Comstock) on date palm in North Sinai, P.ziziphi on citrus (Citrus sp.) in Cairo. Thirty leaves inches of citrus, Ficus nitida, mango, oleander (Oleander sp.) and thirty leaflet of date palm (Phonix dactyllifera) from different locations were stored in well-ventilated glass tubes for one week for emergence the adult parasitoid and for identification and counted. Rate of parasitism was determined by dividing the number of emerging parasitoid from each by the number of hosts existing.

Simple correlation and regression values were calculated to obtain information about the relationships between the three tested weather factors and percent parasitism by studied parasitoid.

\section{RESULTS AND DISCUSSION}

Ten collected armored scale insect species were associated with the parasitoid, $H$. diaspidi. These are:

1. Aonidiella aurantii (Maskell)

2. Aonidiella citrina (Coquillett)

3. Aspidiotus nerii Bouche

4. Chrysomphalus aonidum (Linnaeus)

5. Chrysomphalus dictyospermi (Morgan)

6. Hemiberlesia lataniae (Signoret)

7. Lepidosaphes beckii (Newman)

8. Lepidosaphes pallida (Maskell)

9. Mycetaspis personata (Comstock)

10. Parlatoria ziziphi (Lucas) 


\section{On Aonidiella aurantii (Maskell)}

The population of $A$. aurantii reached its peak in October with 7510 and 7954 individuals / sample during the first and second years, respectively (Fig.1). The parasitoid $H$. diaspidi recorded here was associated with $A$. aurantii infested citrus in Beni Seuf. The results indicated that the maximum parasitism rate reached 20.5 and $21.5 \%$ during November in the first and second years, respectively . While the lowest parasitism rates was 1.2 and 2.6 $\%$ during February in the first and second years, respectively (Fig.2).

In the first year 2010, statistical analysis showed that the simple correlation between the population of parasitoid, minimum temperature and percent of relative humidity and the mean number of $A$. aurantii were non-significant $(r=0.21,0.23$ and 0.18), while significant was recorded between maximum temperature and the population of $A$. aurantii $(r=0.91)$. Also, Statistical analysis showed that the simple regression for changing the population of parasitoid, minimum temperature and $\%$ relative humidity and the mean number of $A$. aurantii were non-significant ( $b=0.19$, 0.31 and 0.23 ), while significant was proved between maximum temperature and the population of $A$. aurantii $(\mathrm{b}=0.95)$. In the second year 2011 , statistical analysis showed that the simple correlation between the population of parasitoid, minimum temperature and $\%$ of relative humidity and the mean number of $A$. aurantii were non-significant ( $r=0.13,0.25$ and 0.30$)$, while significant between maximum temperature and the population of $A$. aurantii $(r=0.90)$. Also, statistical analysis showed that the simple regression for changing the population of parasitoid, minimum temperature and \%relative humidity and the mean number of $A$. aurantii were nonsignificant ( $b=0.25,0.28$, and 0.30 ), while significant between maximum temperature and the population of $A$. aurantii ( $\mathrm{b}=0.87$ ) .

\section{On Aonidiella citrina (Coquillett)}

The population of $A$. citrina reached its peak in October with 457 and 154 individuals / sample during the first and second years, respectively (Fig.3). The parasitoid $H$. diaspidi recorded here associated with $A$. citrina infested citrus in Behira. The results indicated that the maximum parasitism rate reached 55.6 and $55.7 \%$ during November in the first and second years, respectively. While the lowest parasitism rates was 11.2 and $12.6 \%$ during January in the first and second years, respectively (Fig.4).

In the first year 2010, statistical analysis showed that the simple correlation between the population of parasitoid, minimum temperature and percent of relative humidity and the mean number of $A$. citrina were non-significant $(r=0.22,0.21$ and 0.24 ), while showed significant between maximum temperature and the population of 
A. citrina ( $r=0.70$. Also, Statistical analysis showed that the simple regression for changing the population of parasitoid, minimum temperature and \%relative humidity and the mean number of $A$. citrina were non-significant $(b=0.24,0.38$ and 0.40$)$, while proved significant between maximum temperature and the population of $A$. citrina ( $b=0.88)$. In the second year 2011 , statistical analysis showed that the simple correlation between the population of parasitoid, minimum temperature and $\%$ of relative humidity and the mean number of $A$. citrina were non-significant ( $r=0.34$, 0.39 and 0.40 ), while significant between maximum temperature and the population of $A$. citrina $(r=0.79)$. Also, statistical analysis showed that the simple regression for changing the population of parasitoid, minimum temperature and \%relative humidity and the mean number of $A$. citrina were non-significant $(b=0.44,0.58$, and 0.36 ), while significant between maximum temperature and the population of $A$. citrina $(\mathrm{b}=$ 0.91).

\section{On Aspidiotus nerii Bouche}

The population of $A$. nerii reached its peak in October and September with 4781 and 1451 individuals / sample during the first and second years, respectively (Fig.5). The parasitoid $H$. diaspidi recorded here associated with $A$. nerii infested oleander in Giza. The results indicated that the maximum parasitism rate reached 41.8 and $60.4 \%$ during November and October in the first and second years, respectively . While the lowest parasitism rates was 15.9 and $18.9 \%$ during January in the first and second years, respectively (Fig.6).

In the first year 2010, statistical analysis showed that the simple correlation between the population of parasitoid, minimum temperature and percent of relative humidity and the mean number of $A$. nerii were non-significant $(r=0.17,0.19$ and $0.15)$, while showed significant between maximum temperature and the population of A. nerii $(r=0.68$. Also, Statistical analysis showed that the simple regression for changing the population of parasitoid, minimum temperature and \%relative humidity and the mean number of $A$. nerii were non-significant ( $b=0.14,0.22$ and 0.18 ), while significant between maximum temperature and the population of $A$. nerii $(b=0.66)$. In the second year 2011, statistical analysis showed that the simple correlation between the population of parasitoid, minimum temperature and \%of relative humidity and the mean number of $A$. nerii were non-significant $(r=0.15,0.19$ and 0.26 ), while proved significant between maximum temperature and the population of A. nerii $(r=0.64)$. Also, statistical analysis showed that the simple regression for changing the population of parasitoid, minimum temperature and \%relative humidity and the mean number of $A$. nerii were non-significant ( $b=0.14,0.16$, and 0.24 ), 
while significant between maximum temperature and the population of $A$. nerii ( $b=$ 0.61).

\section{On Chrysomphalus aonidum (Linnaeus)}

The population of $C$. aonidum reached its peak in October with 7421 and 7210 individuals / sample during the first and second years, respectively (Fig.7). The parasitoid $H$. diaspidi recorded here associated with $C$. aonidum infested citrus in Qalyubiya. The results indicated that the maximum parasitism rate reached 31.4 and $33.9 \%$ during October in the first and second years, respectively . While the lowest parasitism rates was 7.7 and $10.2 \%$ during February in the first and second years, respectively (Fig.8).

In the first year 2010, statistical analysis showed that the simple correlation between the population of parasitoid, minimum temperature and percent of relative humidity and the mean number of $C$. aonidum were non-significant $(r=0.40,0.35$ and 0.43 , while proved significant between maximum temperature and the population of $C$. aonidum ( $r=0.85$. Also, Statistical analysis showed that the simple regression for changing the population of parasitoid, minimum temperature and \%relative humidity and the mean number of $C$. aonidum were non-significant $(b=$ $0.34,0.41$ and 0.29 ), while significant between maximum temperature and the population of $C$. aonidum $(b=0.81$ ). In the second year 2011 , statistical analysis showed that the simple correlation between the population of parasitoid, minimum temperature and \%of relative humidity and the mean number of $C$. aonidum were non-significant $(r=0.39,0.46$ and 0.45$)$, while showed significant between maximum temperature and the population of $C$. aonidum $(r=0.87)$. Also, statistical analysis showed that the simple regression for changing the population of parasitoid, minimum temperature and $\%$ relative humidity and the mean number of $C$. aonidum were nonsignificant ( $b=0.36,0.39$, and 0.44 ), while significant between maximum temperature and the population of $C$. aonidum $(b=0.93)$.

\section{On Chrysomphalus dictyospermi (Morgan)}

The population of $C$. dictyospermi reached its peak in October with 6210 and 4550 individuals / sample during the first and second years, respectively (Fig.9). The parasitoid, $H$. diaspidi recorded here associated with $C$. dictyospermi infested Ficus nitida in Qalyubiya. The results indicated that the maximum parasitism rate reached 36.8 and $52.6 \%$ during November and October in the first and second years, respectively. While the lowest parasitism rates was 14.5 and $14.8 \%$ during January in the first and second years, respectively (Fig.10). 
In the first year 2010, statistical analysis showed that the simple correlation between the population of parasitoid, minimum temperature and percent of relative humidity and the mean number of $C$. dictyospermi were non-significant $(r=0.22$, 0.24 and 0.26 ), while showed significant between maximum temperature and the population of $C$. dictyospermi ( $r=0.85$. Also, Statistical analysis showed that the simple regression for changing the population of parasitoid, minimum temperature and \%relative humidity and the mean number of $C$. dictyospermi were non-significant ( $b=0.25,0.35$ and 0.33 ), while significant between maximum temperature and the population of $C$. dictyospermi $(b=0.79)$. In the second year 2011 , statistical analysis showed that the simple correlation between the population of parasitoid, minimum temperature and \%of relative humidity and the mean number of $C$. dictyospermi were non-significant ( $r=0.25,0.36$ and 0.39 ), while showed significant between maximum temperature and the population of $C$. dictyospermi $(r=0.88)$. Also, statistical analysis showed that the simple regression for changing the population of parasitoid, minimum temperature and \%relative humidity and the mean number of $C$. dictyospermi were non-significant ( $b=0.23,0.29$ and 0.35 ), while significant between maximum temperature and the population of $C$. dictyospermi $(b=0.90)$.

\section{On Hemiberlesia lataniae (Signoret)}

The population of $H$. lataniae reached its peak in October with 2115 and 1250 individuals / sample during the first and second years, respectively (Fig.11). The parasitoid $H$. diaspidi recorded here associated with $H$. lataniae infested mango in Ismailia. The results indicated that the maximum parasitism rate reached 56.8 and $77.8 \%$ during October and November in the first and second years, respectively . While the lowest parasitism rates was 14.9 and $17.5 \%$ during January in the first and second years, respectively (Fig.12).

In the first year 2010 , statistical analysis showed that the simple correlation between the population of parasitoid, minimum temperature and percent of relative humidity and the mean number of $H$. lataniae were non-significant $(r=0.18,0.21$ and 0.25 ), while showed significant between maximum temperature and the population of $H$. lataniae $(r=0.83$. Also, Statistical analysis showed that the simple regression for changing the population of parasitoid, minimum temperature and \%relative humidity and the mean number of $H$. lataniae were non-significant $(b=0.32,0.35$ and 0.35$)$, while significant between maximum temperature and the population of $H$. lataniae $(b$ $=0.89)$. In the second year 2011, statistical analysis showed that the simple correlation between the population of parasitoid, minimum temperature and \%of relative humidity and the mean number of $H$. lataniae were non-significant $(r=0.24$, 0.23 and 0.31 ), while significant between maximum temperature and the population 
of $H$. lataniae $(r=0.82)$. Also, statistical analysis showed that the simple regression for changing the population of parasitoid, minimum temperature and \%relative humidity and the mean number of $H$. lataniae were non-significant $(b=0.38,0.40$, and 0.43 ), while significant between maximum temperature and the population of $H$. lataniae $(\mathrm{b}=0.82)$.

\section{On Lepidosaphes beckii (Newman)}

The population of $L$. beckii reached its peak in October with 6500 and 6510 individuals / sample during the first and second years, respectively (Fig.13). The parasitoid $H$. diaspidi recorded here associated with $L$. beckii infested mango in Sharqiya. The results indicated that the maximum parasitism rate reached 30.8 and $31.9 \%$ during November and October in the first and second years, respectively. While the lowest parasitism rates was 5.4 and $10.6 \%$ during February and January in the first and second years, respectively (Fig.14).

In the first year 2010, statistical analysis showed that the simple correlation between the population of parasitoid, minimum temperature and percent of relative humidity and the mean number of $L$. beckii were non-significant $(r=0.45,0.44$ and 0.35 ), while significant between maximum temperature and the population of $L$. beckii ( $r=0.85$. Also, Statistical analysis showed that the simple regression for changing the population of parasitoid, minimum temperature and \%relative humidity and the mean number of $L$. beckii were non-significant $(b=0.36,0.39$ and 0.31$)$, while significant showed between maximum temperature and the population of $L$. beckii $(b$ $=0.95)$. In the second year 2011, statistical analysis showed that the simple correlation between the population of parasitoid, minimum temperature and \%of relative humidity and the mean number of $L$. beckii were non-significant ( $r=0.45$, 0.42 and 0.30 ), while significant between maximum temperature and the population of $L$. beckii $(r=0.92)$. Also, statistical analysis showed that the simple regression for changing the population of parasitoid, minimum temperature and \%relative humidity and the mean number of $L$. beckii were non-significant ( $b=0.47,0.45$, and 0.49 ), while significant between maximum temperature and the population of $L$. beckii $(b=$ $0.80)$.

\section{On Lepidosaphes pallida (Maskell)}

The population of L. pallida reached its peak in October with 8210 and 7200 individuals / sample during the first and second years, respectively (Fig.15). The parasitoid $H$. diaspidi recorded here associated with $L$. pallida infested mango in Qalyubiya. The results indicated that the maximum parasitism rate reached 25.4 and $25.7 \%$ during November in the first and second years, respectively . While the 
lowest parasitism rates was 3.6 and $4.2 \%$ during February and March in the first and second years, respectively (Fig.16).

In the first year 2010, statistical analysis showed that the simple correlation between the population of parasitoid, minimum temperature and percent of relative humidity and the mean number of $L$. pallida were non-significant $(r=0.14,0.12$ and 0.18 ), while significant between maximum temperature and the population of $L$. pallida $(r=0.58$. Also, Statistical analysis showed that the simple regression for changing the population of parasitoid, minimum temperature and \%relative humidity and the mean number of $L$. pallida were non-significant $(b=0.12,0.15$ and 0.18$)$, while significant between maximum temperature and the population of $L$. pallida $(b=$ 0.65). In the second year 2011, statistical analysis showed that the simple correlation between the population of parasitoid, minimum temperature and \%of relative humidity and the mean number of $L$. pallida were non-significant $(r=0.23$, 0.28

and 0.31), while proved significant between maximum temperature and the population of $L$. pallida $(r=0.71)$. Also, statistical analysis showed that the simple regression for changing the population of parasitoid, minimum temperature and \%relative humidity and the mean number of $L$. pallida were non-significant $(b=0.11$, 0.15 , and 0.18 ), while significant between maximum temperature and the population of L. pallida $(b=0.85)$.

\section{On Mycetaspis personata (Comstock)}

The population of $M$. personata reached its peak in October with 7415 and 6231 individuals / sample during the first and second years, respectively (Fig.17). The parasitoid $H$. diaspidi recorded here associated with $M$. personata infested date palm in North Sinai. The results indicated that the maximum parasitism rate reached 41.4 and $44.7 \%$ during November and October in the first and second years, respectively . While the lowest parasitism rates was 12.7 and $13.8 \%$ during March and January in the first and second years, respectively (Fig.18).

In the first year 2010, statistical analysis showed that the simple correlation between the population of parasitoid, minimum temperature and percent of relative humidity and the mean number of $M$. personata were non-significant $(r=0.44,0.48$ and 0.47 ), while significant between maximum temperature and the population of $M$. personata $(r=0.85)$. Also, Statistical analysis showed that the simple regression for changing the population of parasitoid, minimum temperature and \%relative humidity and the mean number of $M$. personata were non-significant $(b=0.42,0.44$ and 0.35 ), while significant between maximum temperature and the population of $M$. personata $(b=0.91)$. In the second year 2011 , statistical analysis showed that the 
simple correlation between the population of parasitoid, minimum temperature and $\%$ of relative humidity and the mean number of $M$. personata were non-significant ( $r=$ $0.39,0.43$ and 0.46 ), while showed significant between maximum temperature and the population of $M$. personata $(r=0.97)$. Also, statistical analysis showed that the simple regression for changing the population of parasitoid, minimum temperature and \%relative humidity and the mean number of $M$. personata were non-significant ( $b$ $=0.49,0.46$, and 0.42), while significant between maximum temperature and the population of $M$. personata $(b=0.95)$.

\section{On Parlatoria ziziphi (Lucas)}

The population of $P$. ziziphi reached its peak in October with 7351 and 6541 individuals / sample during the first and second years, respectively (Fig.19). The parasitoid $H$. diaspidi recorded here associated with $P$. ziziphi infested citrus in Cairo. The results indicated that the maximum parasitism rate reached 24.9 and $27.6 \%$ during October in the first and second years, respectively. While the lowest parasitism rates was 4.5 and $5.6 \%$ during February in the first and second years, respectively (Fig.20).

In the first year 2010, statistical analysis showed that the simple correlation between the population of parasitoid, minimum temperature and percent of relative humidity and the mean number of $P$. ziziphi were non-significant $(r=0.14,0.20$ and $0.19)$, while significant between maximum temperature and the population of $P$. ziziphi ( $r=0.70$. Also, Statistical analysis showed that the simple regression for changing the population of parasitoid, minimum temperature and \%relative humidity and the mean number of $P$. ziziphi were non-significant $(b=0.20,0.32$ and 0.19$)$, while significant between maximum temperature and the population of $P$. ziziphi $(b=$ 0.72) . In the second year 2011, statistical analysis showed that the simple correlation between the population of parasitoid, minimum temperature and \%of relative humidity and the mean number of $P$. ziziphi were non-significant $(r=0.15$, 0.14 and 0.22 ), while significant between maximum temperature and the population of $P$. ziziphi $(r=0.74)$. Also, statistical analysis showed that the simple regression for changing the population of parasitoid, minimum temperature and \%relative humidity and the mean number of $P$. ziziphi were non-significant $(b=0.34,0.38$, and 0.42$)$, while significant between maximum temperature and the population of $P$. ziziphi $(b=$ $0.86)$. 


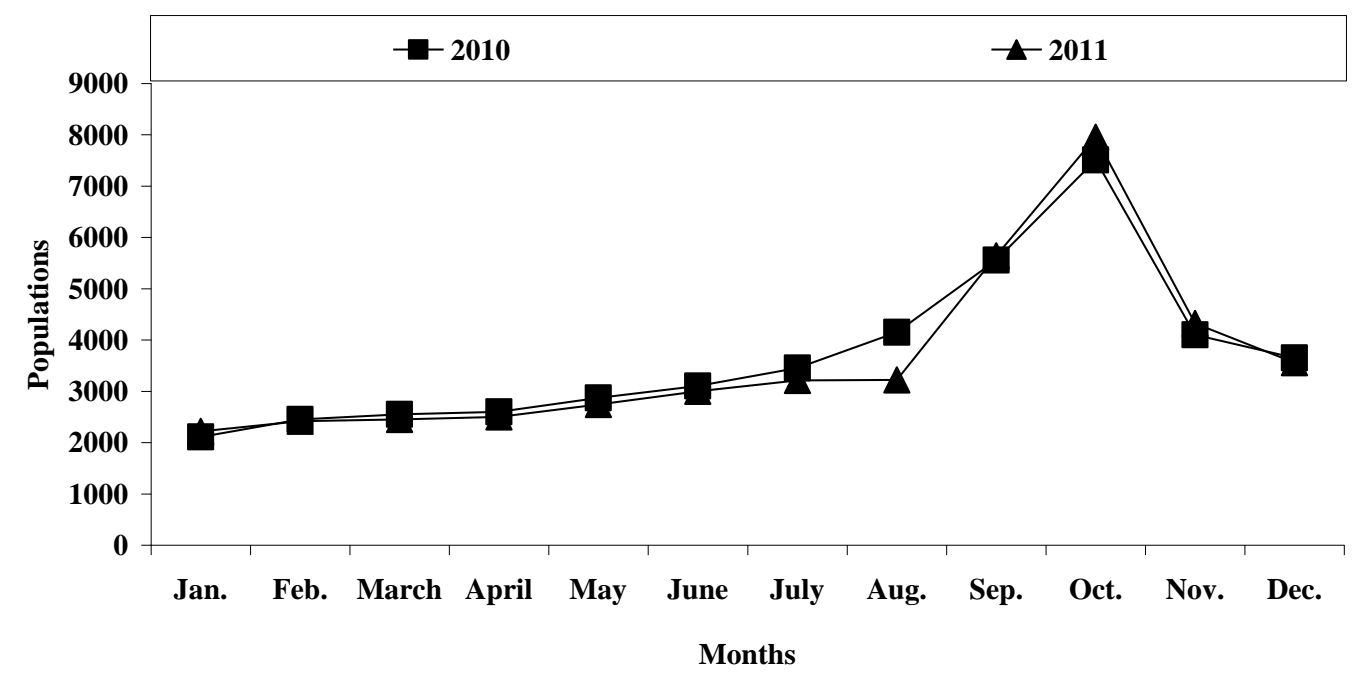

Fig.1: Population dynamics of Aonidiella aurantii on citrus in Beni-Suef

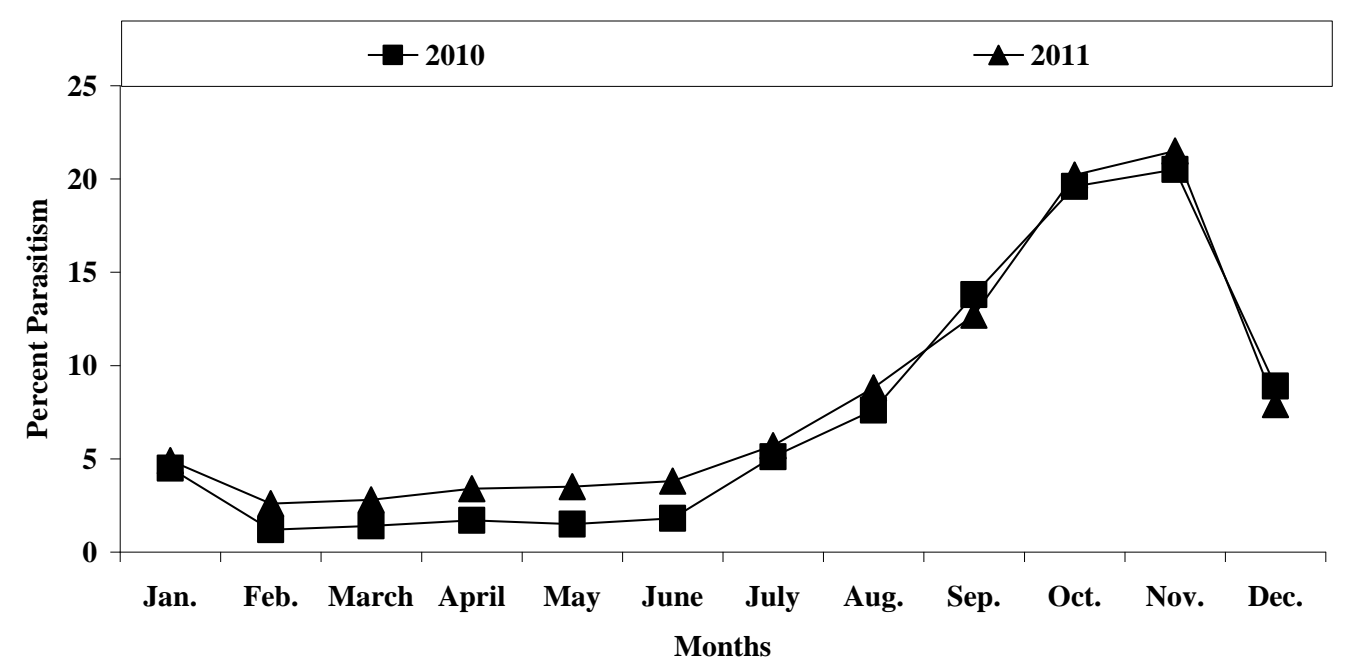

Fig.2: Perecent Parasitism by Habrolepis diaspidi associated with Aonidiella aurantii on citrus in Beni-Suef 


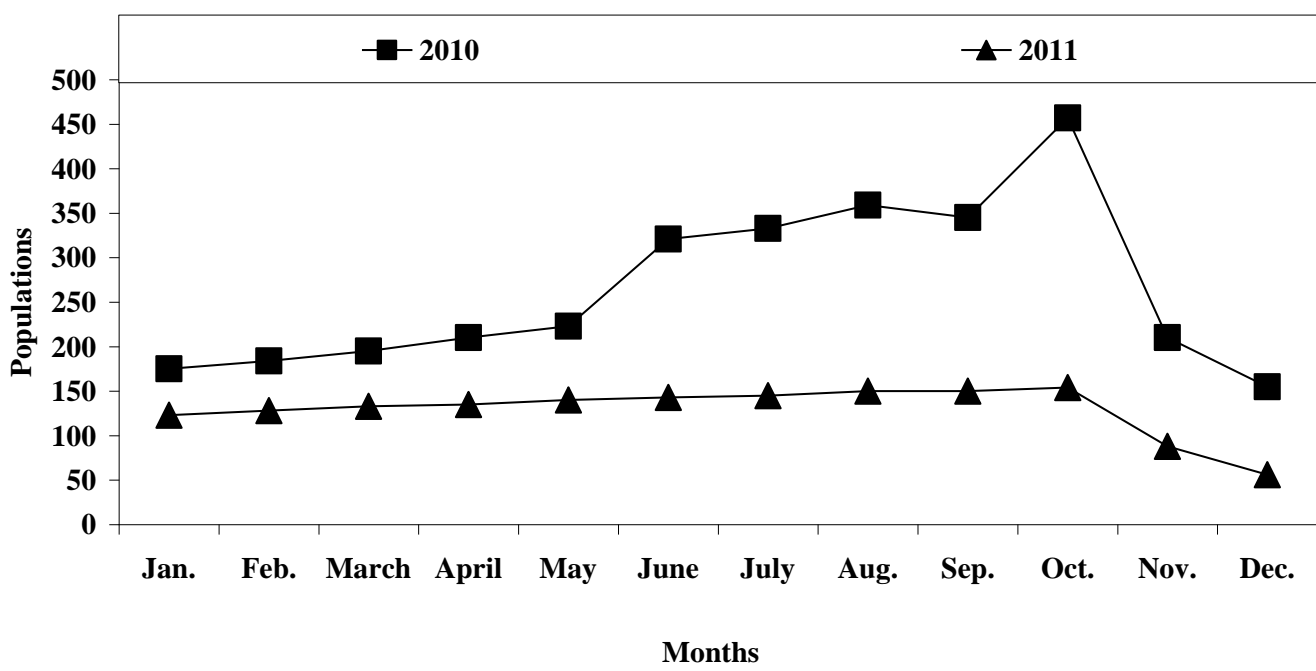

Fig.3: Population dynamics of Aonidiella citrina on citrus in Behira

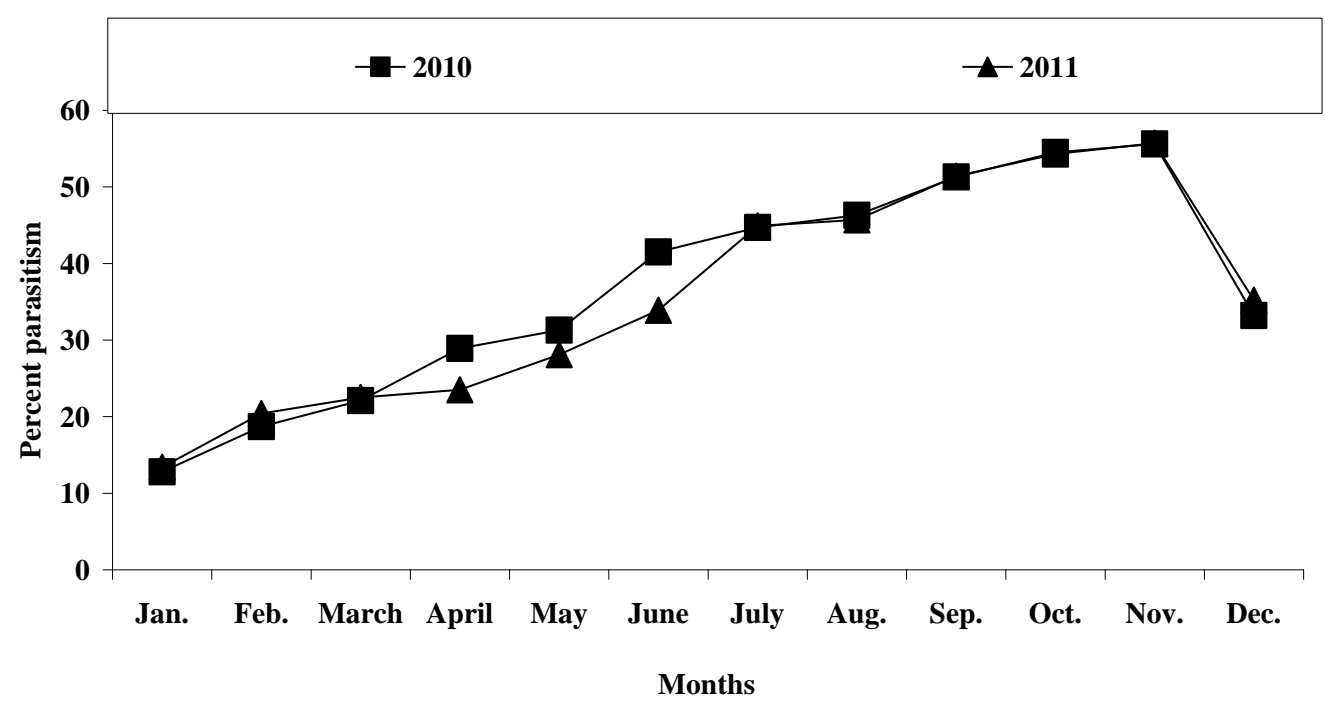

Fig.4: Percent parasitism by Habrolepis diaspidi associated with Aonidiella citrina on citrus in Behira 


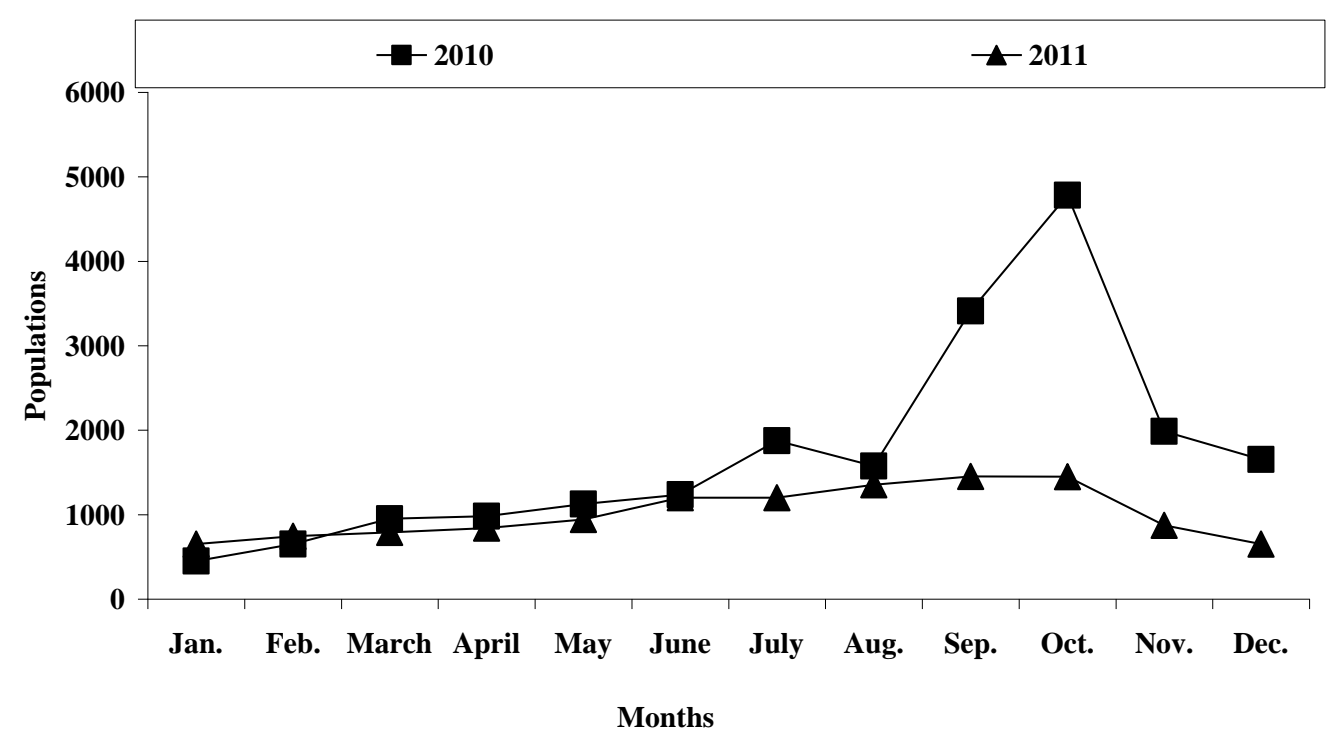

Fig.5: Population dynamics of Aspidiotus nerii on oleander in Giza

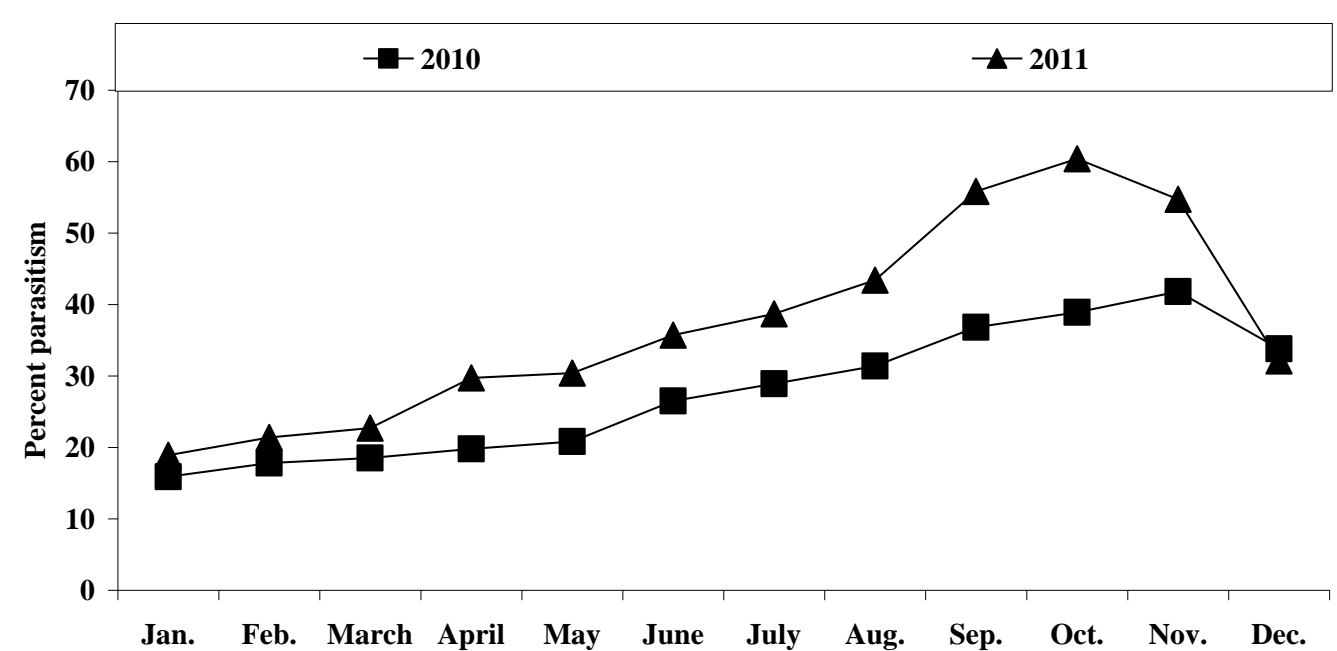

Months

Fig.6: Percent parasitism by Habrolepis diaspidi associated with Aspidiotus nerii on oleander in Giza 


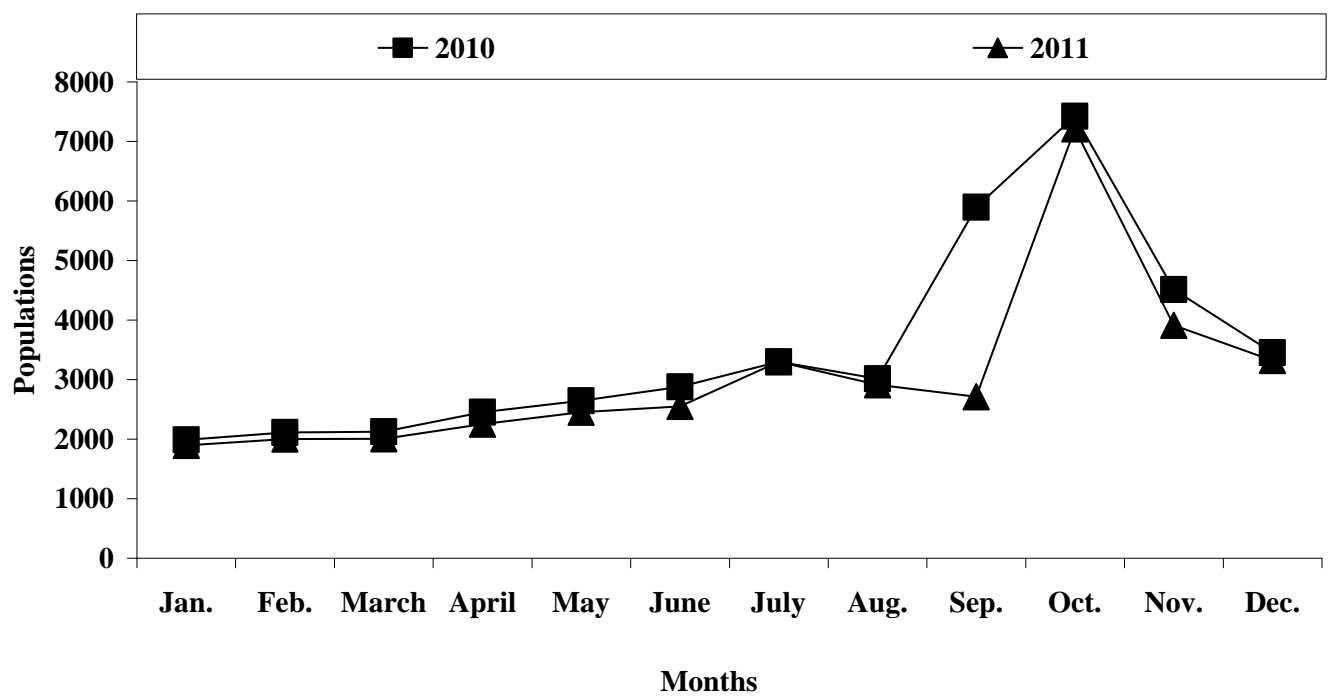

Fig.7: Population dynamics of Chrysomphalus aonidum on citrus in Qalyubiya

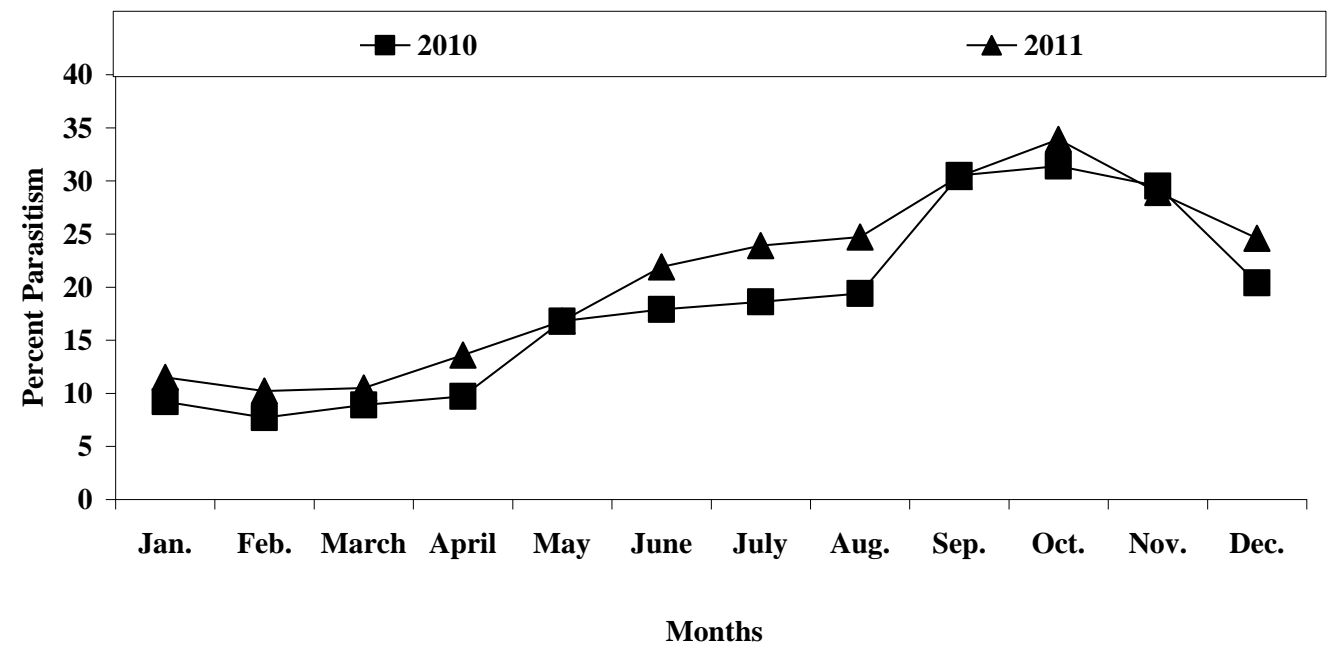

Fig.8: Perecent Parasitism by Habrolepis diaspidi associated with Chrysomphalus aonidum on citrus in Qalyubiya 


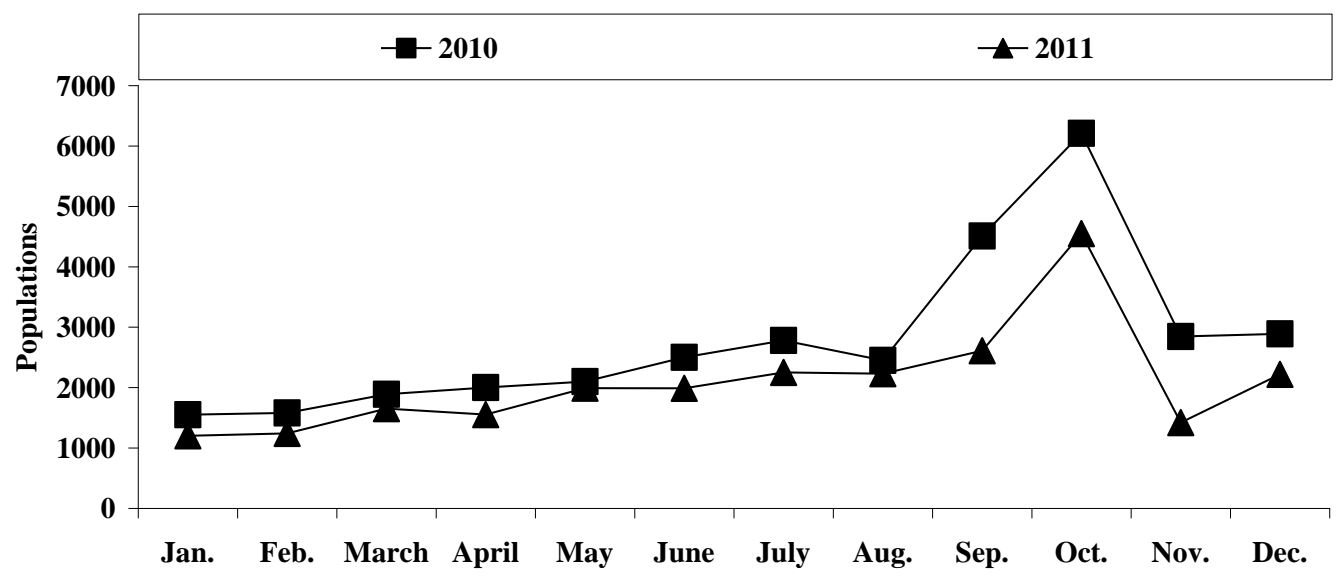

Months

Fig.9: Population dynamics of Chrysomphalus dictyospermi on Ficus nitida in Qalyubiya

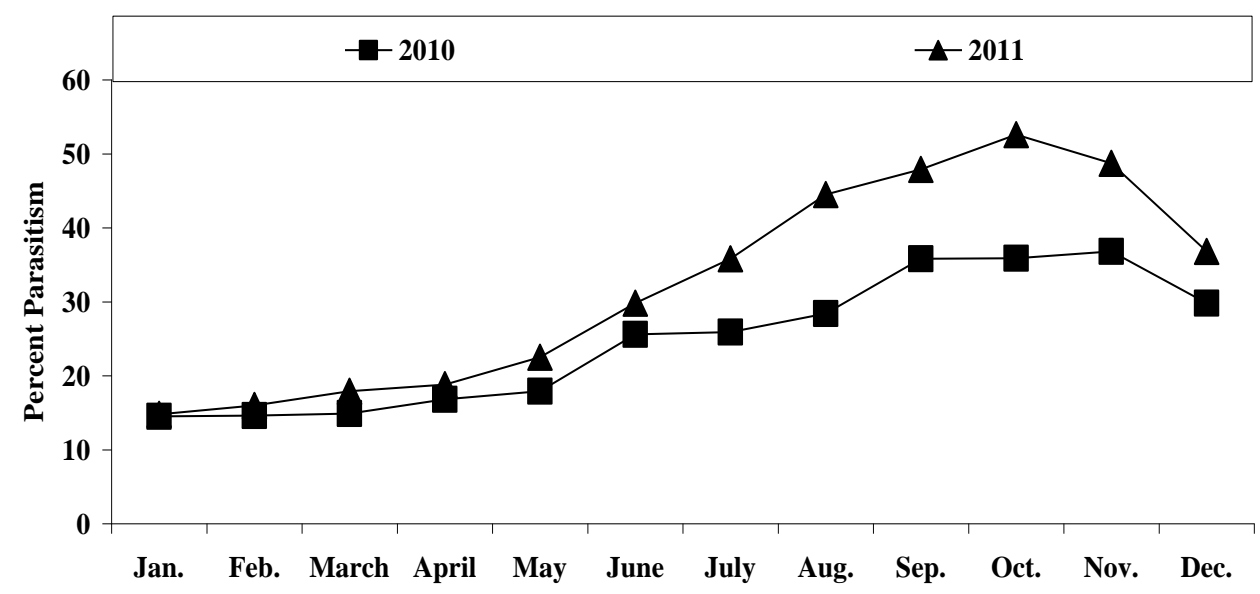

Months

Fig.10: Perecent parasitism by Habrolepis diaspidi associated with Chrysomphalus dictyospermi on Ficus nitida in Qalyubiya 


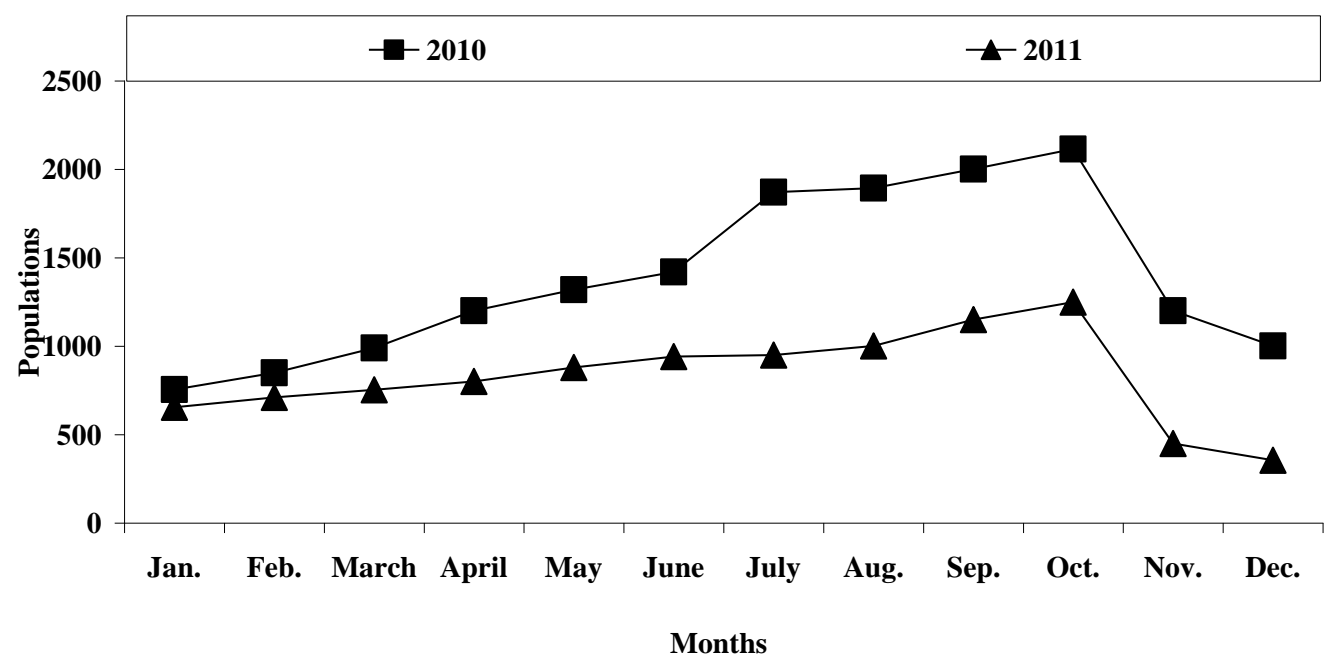

Fig.11: Population dynamics of Hemiberlesia lataniae on mango in Ismailia

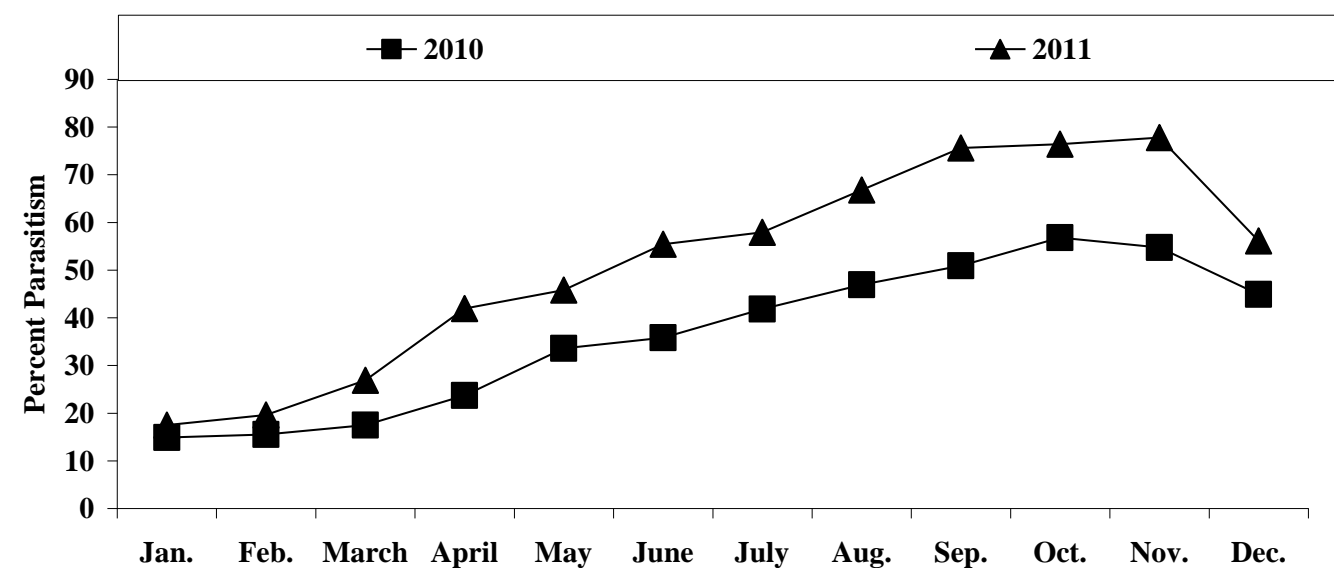

Months

Fig.12: Percent parasitism by Habrolepis diaspidi associated with Hemiberlesia lataniae on mango in Ismailia 


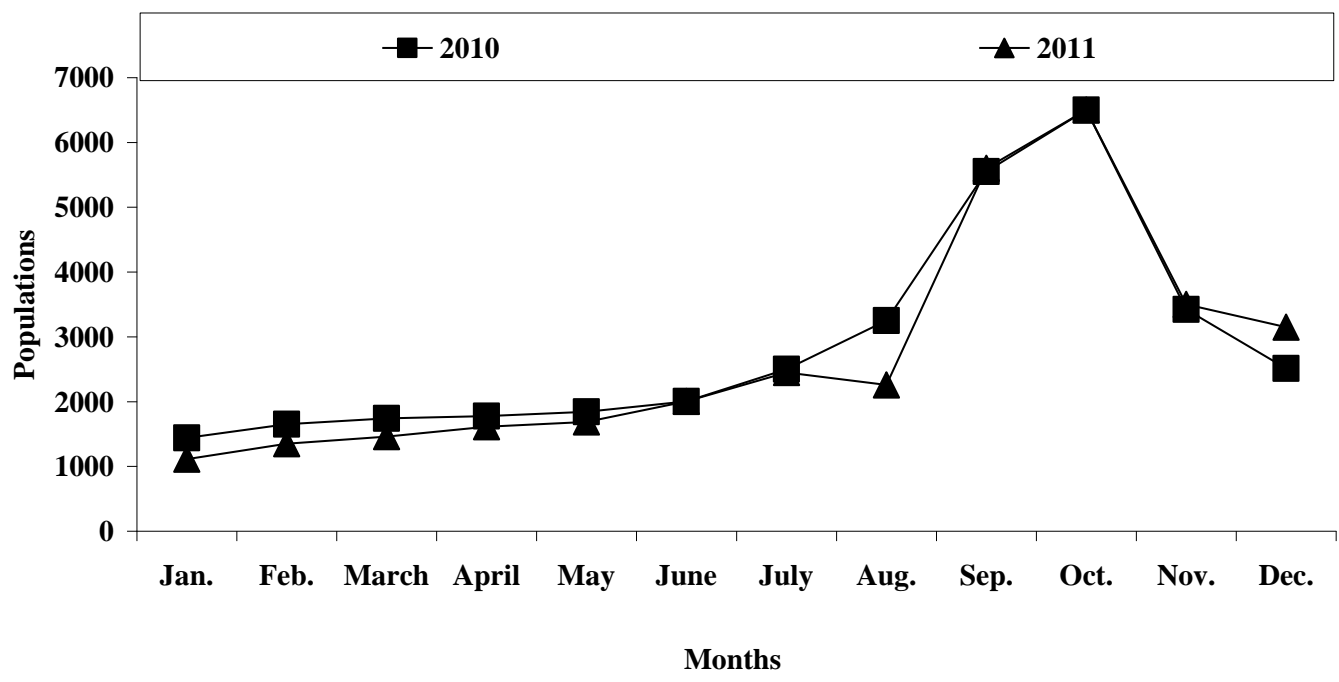

Fig.13: Population dynamics of Lepidosaphes beckii on mango in Sharqyia.

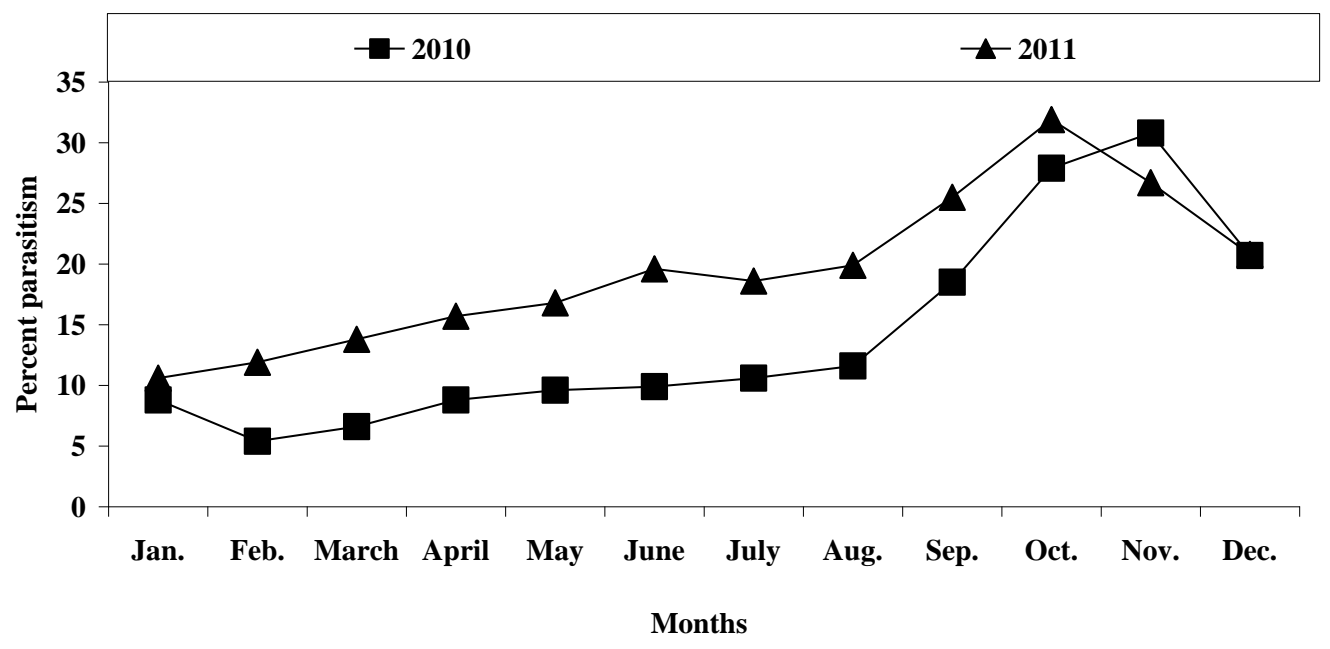

Fig.14: Percent parasitism by Habrolepis diaspidi associated with Lepidosaphes beckii on mango in Sharqyia. 


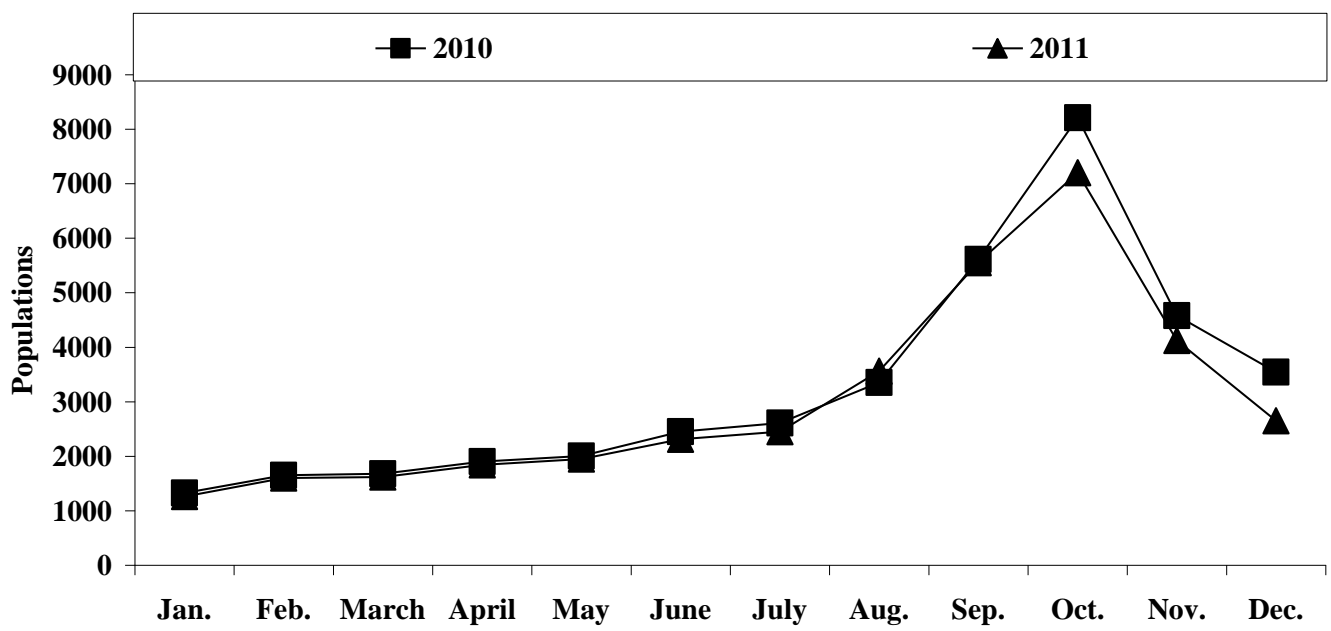

Months

Fig.15: Population dynamics of Lepidosaphes pallida on mango in Qalyubiya.

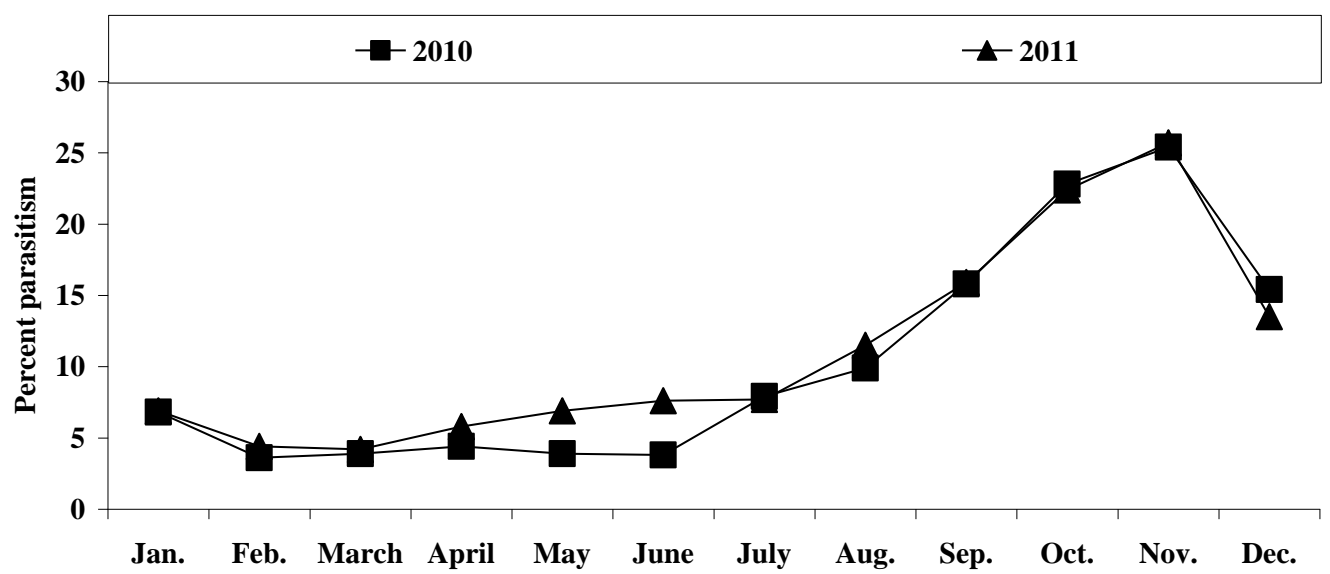

\section{Months}

Fig.16: Percent parasitism by Habrolepis diaspidi associated with Lepidosaphes pallida on mango in Qalyubiya. 


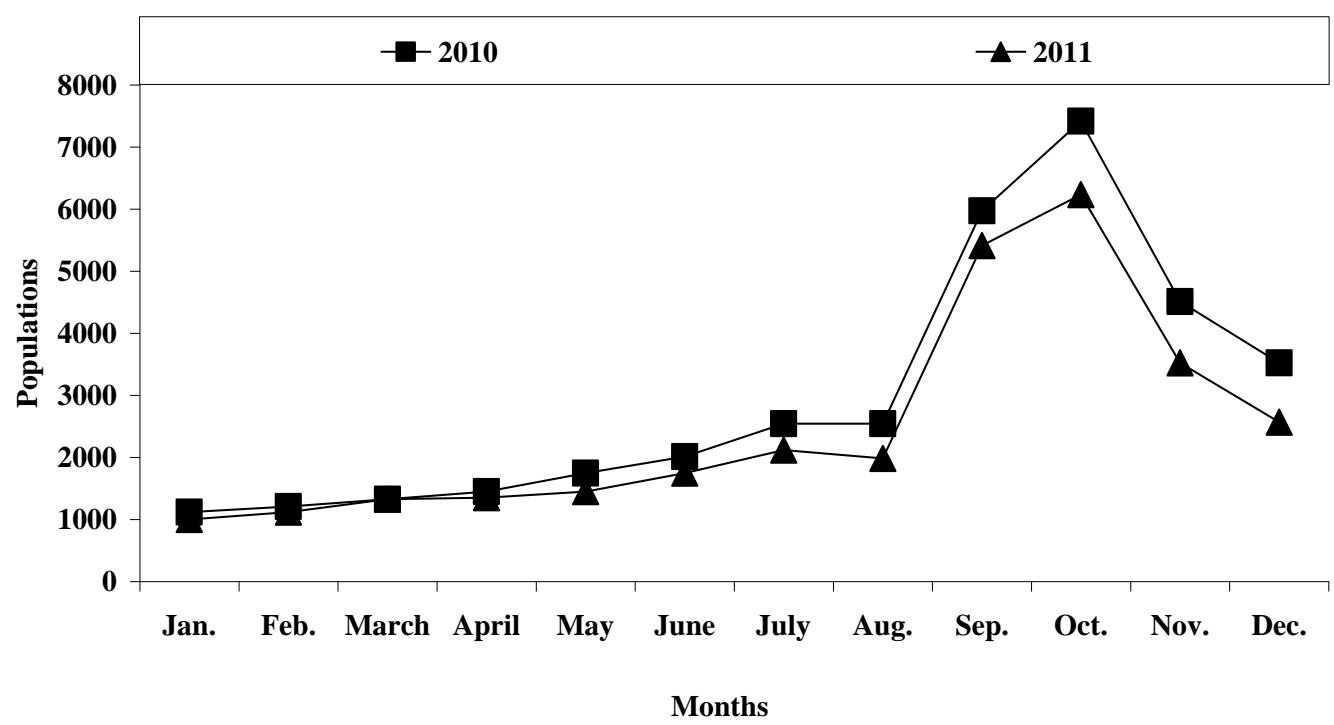

Fig.17: Population dynamics of Mycetaspis personata on date palm in North Sinai .

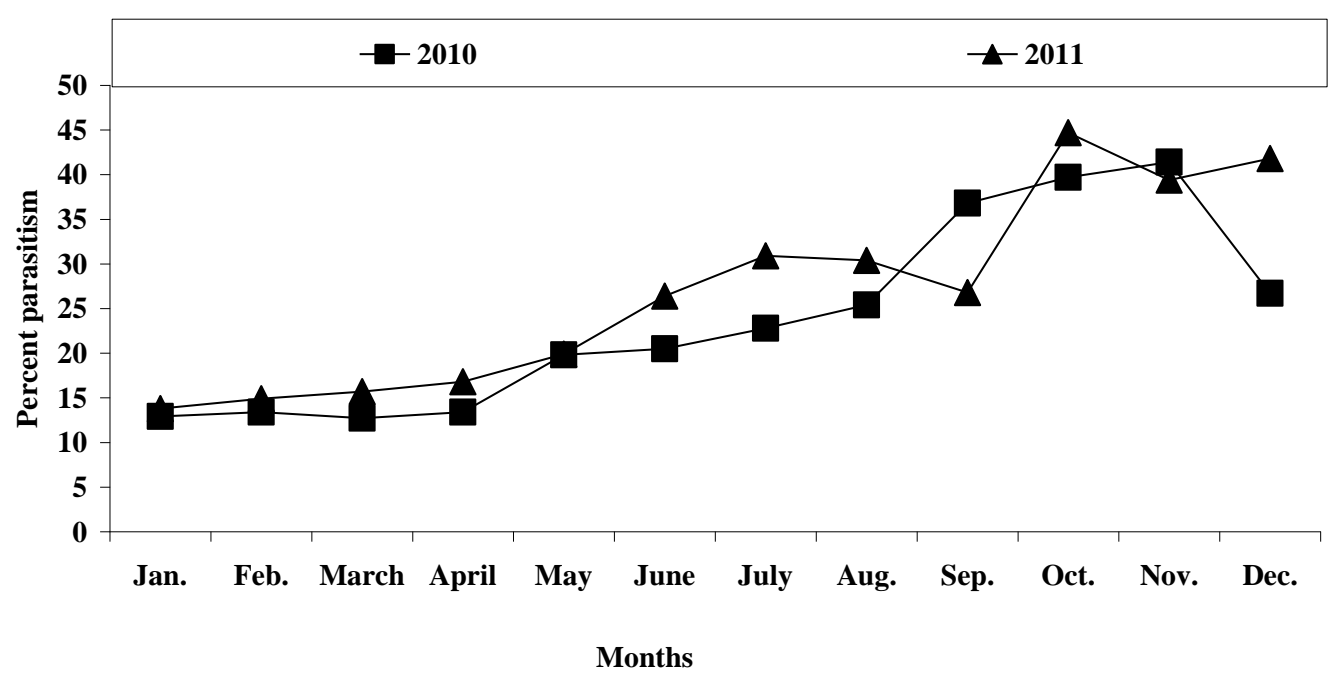

Fig.18: Percent parasitism by Habrolepis diaspidi associated with Mycetaspis personata on date palm in North Sinai 


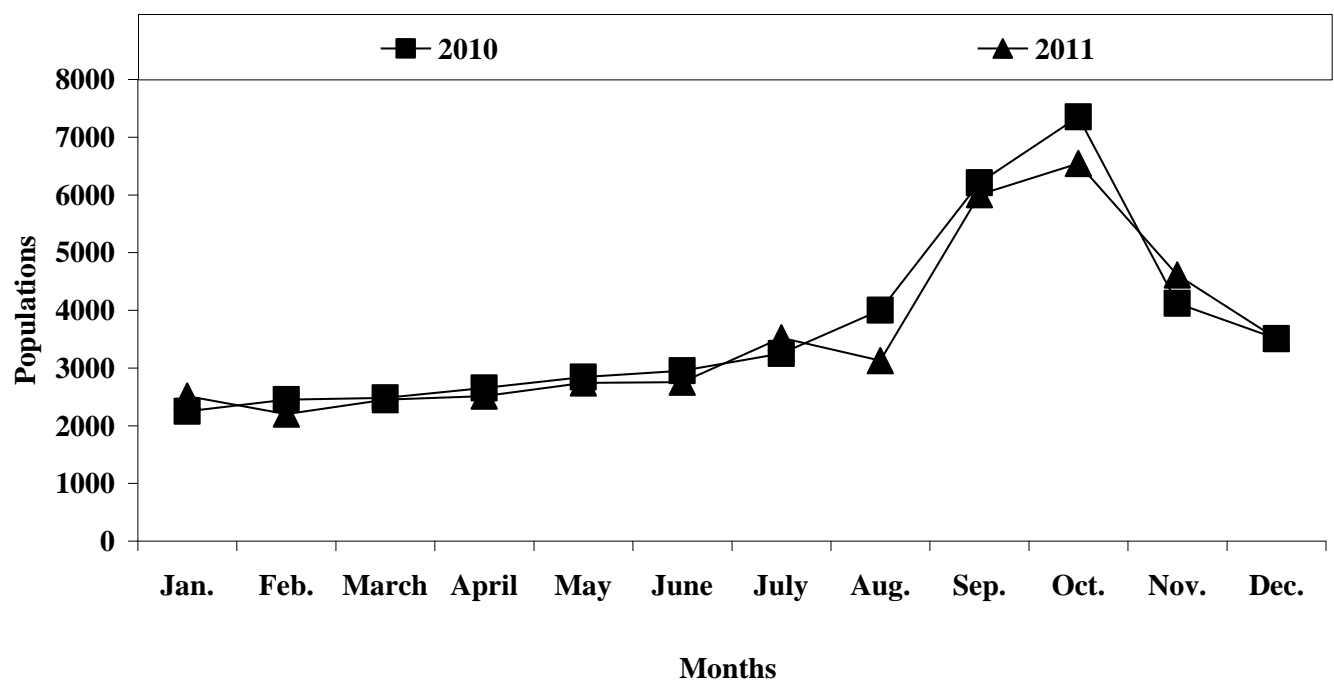

Fig.19: Population dynamics of Parlatoria ziziphi on citrus in Cairo

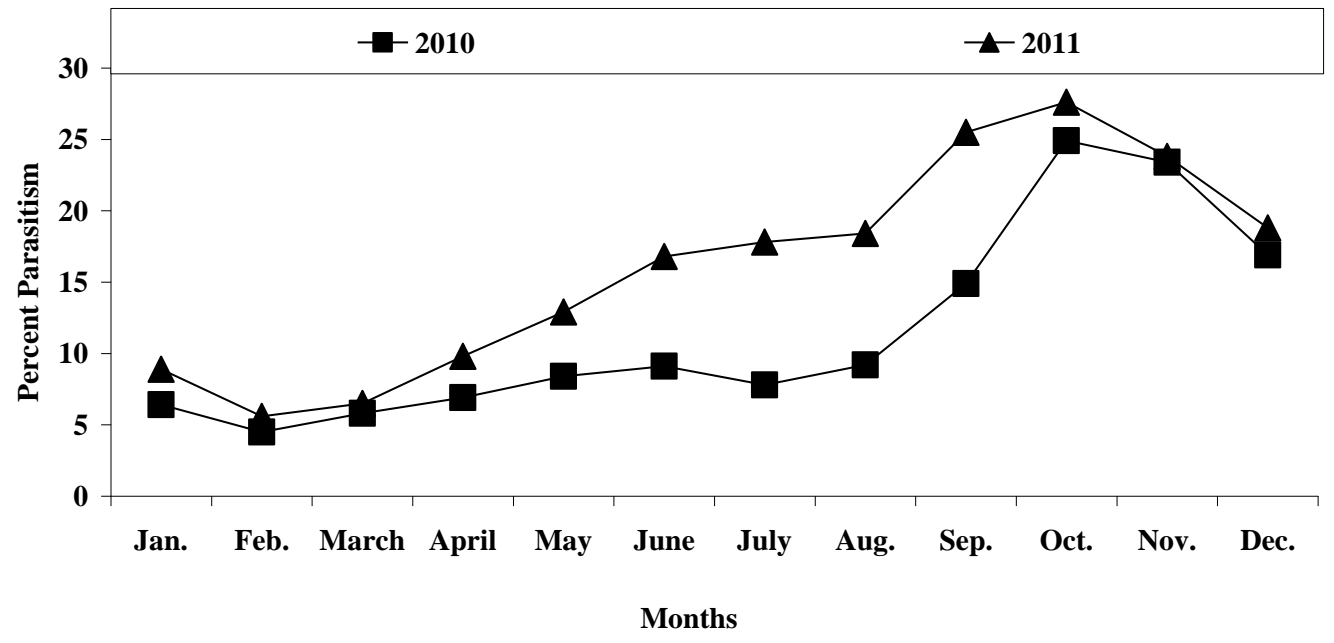

Fig.20: Perecent Parasitism by Habrolepis diaspidi associated with Parlatoria ziziphi on citrus in Cairo 


\section{REFERENCES}

1. Abd-Rabou, S. 1997. Parasitoids attacking some species of scale insects (Homoptera: Coccoidea: Diaspididae) in Egypt. Proceeding of the First Scientific Conference of Agricultural Sciences, Faculty of Agric. Assiut Univ., Vol. II, 727736.

2. Bénassy, C., G. Euverte. 1968. Notes on Chrysomphalus dictyospermi in Morocco. Al Awamia 24:95-111.

3. Coll, M., S. Abd-Rabou. 1998. Effect of oil emulsion sprays on parasitoids of the black parlatoria, Parlatoria ziziphi, in grapefruit BioControl 43(1):29-37.

4. Cilliers, C. J. 1970. Observations on circular purple scale Chrysomphalus aonidum (Linn. ), and two introduced parasites in western Transvaal citrus orchards Biocontrol Volum 16(3):1971 127-148.269-284.

5. Compere, H., D.P. Annecke. 1961. Descriptions of parasitic Hymenoptera and comments (Hymenopt.: Aphelinidae, Encyrtidae, Eulophidae). Journal of the Entomological Society of Southern Africa 24:44.

6. Hassanein, F.A., A.R. Hamed. 1986. On the population dynamics of Hemiberlesia lataniae Signoret and its parasite Habrolepis apsidioti Compere and Annecke in Egypt (Homoptera: Diaspididae, Hymenoptera: Encyrtidae). Bulletin of the Entomological Society of Egypt (Economic Series) 1986:63-72.

7. Mohammad, Z.K., M.W. Ghabbour, M.H. Tawfik. 2001. Population dynamics of Aonidiella orientalis (Newstead) (Coccoidea: Diaspididae) and its parasitoid Habrolepis aspidioti Compere \& Annecke (Hymenoptera: Encyrtidae). Entomologica, Bari 33:413-418

8. Noyes, J.S. and M. Hayat. 1994. Oriental mealybug parasitoids of the Anagyrini (Hymenoptera: Encyrtidae) pp.407 CAB International, Oxon, UK.

9. Tawfik, M.H., Z.K. Mohammad. 2001. Ecological studies of two scale insects (Hemiptera, Coccoidea) on Morus alba in Egypt. Bollettino di Zoologia Agraria e Bachicoltura 33(3):267-273.

10. Trjapitzin, V.A. 1989. Parasitic Hymenoptera of the Fam. Encyrtidae of Palaearctics. Opredeliteli po Faune SSSR 158:293 Zoologicheskim Institutom Akademii Nauk SSR, Leningrad

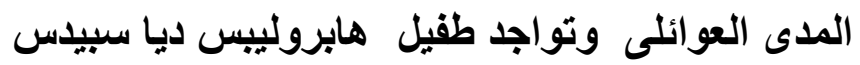




$$
\begin{aligned}
& \text { على الحشرات القشرية المسلحة فى مصر } \\
& \text { شعبان عبد ربه ، هلى بدارى } \\
& \text { معرد بحوث وقاية النباتات - مركز البحوث الزراعية ـ الدقي - جيزة }
\end{aligned}
$$

يعتبر طفيل هابروليبس ديا سبيدس من أهم الطفيليات المؤثرة فى المكافحة البيولوجية للحشرات

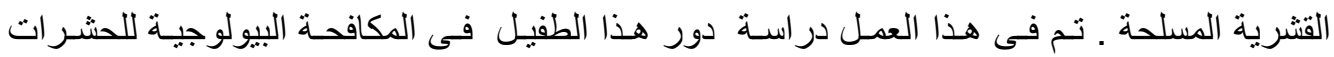

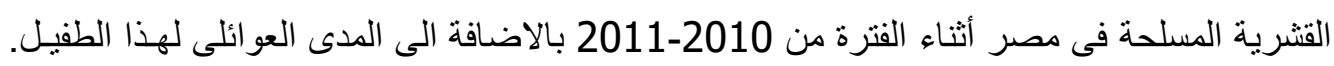

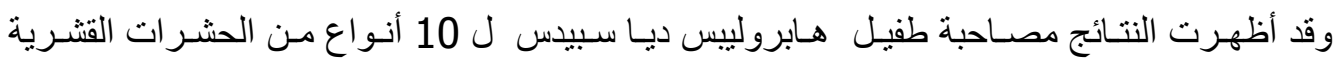
المسلحة وهى

Aonidiella aurantii (Maskell), Aonidiella citrina (Coquillett), Aspidiotus nerii Bouche , Chrysomphalus aonidum , Chrysomphalus dictyospermi (Morgan), Hemiberlesia lataniae (Signoret), Lepidosaphes beckii (Newman), Lepidosaphes pallida (Maskell), Mycetaspis personata (Comstock), Parlatoria ziziphi (Lucas)

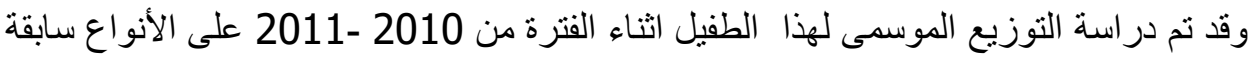

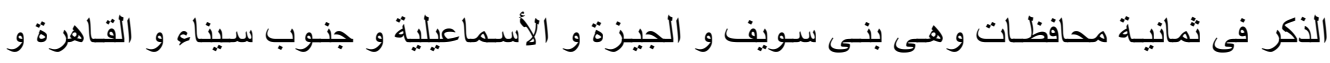

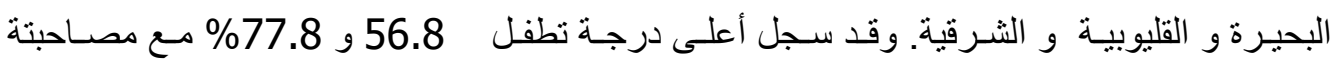

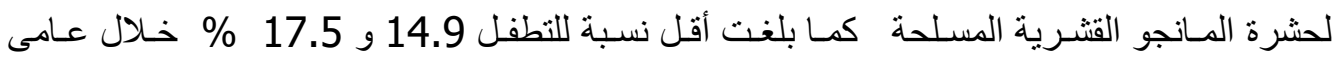
الدراسة ـ و يتضـح من النتـائج ان طفيـل هـابروليبس ديـا سبيدس مـن الطفيليـات الهامـة فـى مكافحـة

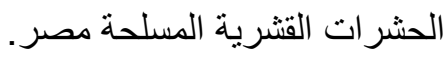

